\title{
State of Play of Anesthesia for Outpatient Medical and Surgical Procedures in the City of Kinshasa
}

\author{
Joseph Tsangu Phuati* ${ }^{*}$, Justin Mboloko Esimo², Antoine Tshimpi Wola ${ }^{3}$, \\ Benjamin Longo-Mbenza ${ }^{3}$, Medard Bulabula Isokuma', Luc Mokassa Bakumobatane ${ }^{4}$, \\ Eric Amisi Bibonge1, Wilfrid Mbombo Dibwe1, Patrick Mukuna Miteo1, \\ Patrick Kobo Utumpu', Heritier Mawalala Malengele ${ }^{3}$, Gibency Mfulani', \\ Berthe Barhayiga Nsimire ${ }^{1}$
}

\begin{abstract}
${ }^{1}$ Department of Anaesthesia and Intensive Care, University Clinics of Kinshasa, Kinshasa, DR Congo
${ }^{2}$ Department of Gynaecology-Obstetrics, University Clinics of Kinshasa, Kinshasa, DR Congo

${ }^{3}$ Department of Internal Medicine, University Clinics of Kinshasa, Kinshasa, DR Congo

${ }^{4}$ Department of Surgery, University Clinics of Kinshasa, Kinshasa, DR Congo

Email: `tsanguphuati@gmail.com, jmboloko@yahoo.fr, antshimpi@aol.com, longombenza@gmail.com,drmebula@gmail.com, mokassasado@gmail.com, eric.amisi@yahoo.fr,pwmbombo@gmail.com,patmukunam@gmail.com, kbpt20013@gmail.com, herimawalala@gmail.com, gibencymfulani1990@gmail.com, berthebarhayiga@gmail.com
\end{abstract}

How to cite this paper: Tsangu Phuati, J. Mboloko Esimo, J., Tshimpi Wola, A., Longo-Mbenza, B., Bulabula Isokuma, M., Mokassa Bakumobatane, L., Amisi Bibonge, E., Mbombo Dibwe, W., Mukuna Miteo, P., Kobo Utumpu, P., Mawalala Malengele, H., Mfulani, G. and Barhayiga Nsimire, B. (2022) State of Play of Anesthesia for Outpatient Medical and Surgical Procedures in the City of Kinshasa. Open Journal of Anesthesiol$o g y, 12,77-90$.

https://doi.org/10.4236/ojanes.2022.122007

Received: January 9, 2022

Accepted: February 21, 2022

Published: February 24, 2022

Copyright $\odot 2022$ by author(s) and Scientific Research Publishing Inc. This work is licensed under the Creative Commons Attribution-NonCommercial International License (CC BY-NC 4.0). http://creativecommons.org/licenses/by-nc/4.0/ (c) (i) (8) Open Access

\begin{abstract}
Context and Objective: The practice of outpatient anaesthesia has many advantages over anesthesia with conventional hospitalisation, particularly in the reduction of post-operative complications and the faster resumption of activity, etc. No study has been carried out on this subject in our community; this study was carried out in order to come up with a concrete state of play when it comes to outpatient anesthesia for medical and surgical procedures in the city of Kinshasa. Methodology: This was a cross-sectional study, which took place in seven hospitals in the city of Kinshasa from 1 November 2020 to 31 January 2021. The population consisted of all patients who received outpatient anesthesia and the included patients had signed an informed consent. The variables of the study were the general profile of patients, surgical procedures and indications, anesthetic data and patient evolution. Statistical analyses were performed with SPPS 21.0 with $\mathrm{p}<0.05$ value. Results: We collected data from 971 patients who had undergone anesthesia in the seven medical facilities in the city of Kinshasa. Among these patients, 394 had benefited from outpatient anesthesia, i.e. a frequency of outpatient anesthesia estimated at $40.5 \%$. Three hundred and ninety-four (394) patients were selected. They were $58.6 \%$ women and $41.4 \%$ men i.e. a sex ratio $\mathrm{M} / \mathrm{F}$ of 0.7 . The mean age was $39.3 \pm 18.7$ years with the extremes of 1 and 82 years. Ga-
\end{abstract}


stroscopy was the most performed (operative) procedure (21.6\%). Patients were classified as ASA 1 in $75.1 \%$, narcosis (80.7\%) using propofol (80.2\%) was the most used anesthetic technique and performed by a specialist doctor in Anesthesia in 65.5\%. Suxamethonium was the most used curare in $13.2 \%$. Fentanyl was the most used opioid in $14.5 \%$. Bupivacaine (10.9\%) was the most widely used local anesthetic. Eleven patients or $3.2 \%$ had complications and, i.e. $(0.8 \%)$ were hospitalized, class ASA II appeared to be a factor associated with complications. Conclusion: Ambulatory anesthesia is a reality in the city of Kinshasa; however, it is still underdeveloped and mainly concerns explorations (gastroscopy, colonoscopy, laparoscopy...) and some minor procedures. This anesthesia mainly uses propofol and is done by the specialist doctor. A high-powered study and an evaluation of this practice in the light of international recommendations would be useful.

\section{Keywords}

Anesthesia, Medical and Surgical, Outpatient Procedures

\section{Introduction}

Outpatient surgery is defined as surgical procedures and/or explorations programmed and performed under technical conditions that imperatively require the safety of an operating room, under anesthesia of variable mode and followed by post-operative monitoring allowing, without increased risk, the discharge of the patient on the same day. Outpatient surgery is therefore a scheduled surgery [1]. Outpatient management of medical and surgical procedures could be the standard of tomorrow, when $50 \%$ to $75 \%$ of these interventions will be performed according to this modality. An increasing number of interventions must already be performed on an ambulatory basis (knee arthroscopy, inguinal hernia cure, etc.) [2].

This method of care is considered to be beneficial in terms of the organization of the care system, the quality of care, patient satisfaction and it is a source of reduction in the cost of care. But it must be carried out under special organizational conditions allowing the patient to benefit from an intervention without additional risk and to be discharged the same day [3]. The duration of outpatient stay is less than 12 hours according the French medical literature and 24 hours according to the Anglo-Saxons [4].

In 2009, a large international survey concluded that it already concerned $83 \%$ of patients who underwent surgery in the USA, 74\% in Denmark, $69 \%$ in Sweden, 53\% in Great Britain, 53\% in Holland, 50\% in Norway, 49\% in Portugal, $43 \%$ in Germany and 35\% in France [5]. In 2017, a study conducted in France had found that it concerned $55.9 \%$ and projected to reach $70 \%$ in 2022 [6].

In Africa, studies on ambulatory anesthesia are scarce. Nevertheless, let us cite that of Khamouna in Morocco which reported the realities and prospects of this 
practice [7] and in the Democratic Republic of Congo (DRC), Luty AN et al. described the clinical profile of tonsillectomy indications in Lubumbashi and found that it was performed on an outpatient basis in 19\% [8]. Ambulatory anesthesia is performed in the Democratic Republic of Congo but we do not have epidemiological data. Hence this study is carried out with the goal of making a state of play when it comes to anesthesia for outpatient medical and surgical procedures in the city of Kinshasa.

\section{Methods}

\subsection{Nature, Setting and Period of Study}

This is a cross-sectional study that ran from November 01, 2020 to January 31, 2021 (i.e. three months). It took place in seven medical facilities in the city of Kinshasa all having an Anesthesia-Resuscitation department with the required equipment, ran by a permanent Anesthesiologist-Resuscitator;

\subsection{Population and Sampling}

The population consisted of patients who underwent outpatient anesthesia in the selected centers. The study used an exhaustive sampling with consecutive recruitment of all patients who underwent surgery or exploration with outpatient anesthesia.

\subsection{Patient Selection}

Were included in the study, all patients who had undergone surgery or exploration with outpatient anesthesia: seen in a pre-anesthetic consultation after a surgical consultation, had given their informed consent, and whose data collection form was correctly filled.

Any patient who underwent an anesthesia performed by the surgeon himself without the involvement of an anesthesiologist doctor, or a non-ambulatory anesthesia, was not included in the study.

Patients who did not give an informed consent and those whose data collection form did not contain all the variables of interest were excluded from the study.

The data processing was carried out in several stages: manual examination of the data collection form; typing; purification and encoding on Microsoft Excel 2013 software.

\subsection{Study Variables}

Concerning the variables of the study, we established a data collection sheet (questionnaire) which allowed us to collect all the necessary information on the progress of the anesthetic management of the medico-surgical acts. Data obtained from different data collection sheets were analyzed. Among its variables we have.

We needed age, sex, estimated distance from home in terms of time, level of 
education as socio-demographic variables.

In the pre-operative period we were looking for: the pre-operative diagnosis, planned operative act and/or exploration, ASA class, prescription of analgesics, delivery of the document concerning the instructions, estimated duration of the operation, pre-anesthetic visit.

In the intraoperative period, we were looking for: the intraoperative diagnosis, procedure performed, qualification of the operator, PONV prevention, type of anesthesia, anesthetic drugs used, complications encountered, actual duration of the operation, administration of analgesics.

In the postoperative period, we had to make sure there was a telephone contact between the patient and the hospital team, the patient had an attendant, whether the patient had returned to the hospital, the discharge score assessed, if there was had thromboembolism prevention.

\subsection{Statistical Analyzes}

Analysis was performed on SPSS software version. Pearson's chi-square test or Ficher's exact test was performed to compare the percentages. Student's T test to compare means. The factors associated with the complications were seeked by logistic regression with the calculation of the odds ratio (OR) in order to determine the degree of risk. The $\mathrm{p}$-value $<0.05$ was defined as the threshold of significance.

\subsection{Ethical Considerations}

This study was approved by the ethics committee of the School of Public Health of the Faculty of Medicine of the University of Kinshasa under the number: $\mathrm{N}^{\circ}$ $\mathrm{ESP} / \mathrm{CE} / 127 \mathrm{~B} / 2020$.

\section{Results}

We collected data from 971 patients who underwent anesthesia in seven medical facilities in the city of Kinshasa province. Among these patients, 394 had received outpatient anesthesia and were the subject of this study, while 577 did not meet our inclusion criteria because they were subject to conventional hospitalization. Hence the frequency of ambulatory anesthesia has been estimated at $40.5 \%$.

\subsection{Patient Profile (See Table 1)}

Among the 394 patients registered, there were 231 women (58.6\%) and 163 men (41.4\%), i.e. a sex ratio $\mathrm{M} / \mathrm{F}$ of 0.7 (163/231). The mean age was $39.3 \pm 18.7$ years with the age ranges of 1 and 82 years, and that of men $43.9 \pm 20.5$ years was higher than that of women $(\mathrm{p}<0.001)$. Most patients were between 21 and 30 years old, i.e. $26.4 \%$ of cases. In most cases medical cares were paid by companies, the distance from home to hospital was less than an hour in $89.8 \%$ and education level was high in $72.8 \%$. 
Table 1. General profile of the study population.

\begin{tabular}{|c|c|c|c|c|}
\hline \multirow[b]{2}{*}{ Variables } & \multirow{2}{*}{$\begin{array}{c}\text { All } \\
\mathrm{n}=394\end{array}$} & \multicolumn{2}{|c|}{ Sex } & \multirow[b]{2}{*}{$\mathbf{P}$} \\
\hline & & $\begin{array}{c}\text { Men } \\
\mathrm{n}=163\end{array}$ & $\begin{array}{l}\text { Women } \\
\mathrm{n}=231\end{array}$ & \\
\hline Age, year & & & & $<0.001$ \\
\hline $\mathrm{X} \pm \mathrm{ET}$ & $39.3 \pm 18.7$ & $43.9 \pm 20.5$ & $36.2 \pm 16.5$ & \\
\hline $\mathrm{Me}(\mathrm{EIQ})$ & $37(26-56)$ & & & \\
\hline \multicolumn{5}{|l|}{ Age groups } \\
\hline$\leq 20$ ans & $49(12.4)$ & $26(53.1)$ & $23(46.9)$ & \\
\hline 21 à 30 ans & $104(26.4)$ & $12(11.5)$ & $92(88.5)$ & \\
\hline 31 à 40 ans & $63(15.9)$ & $25(39.7)$ & $38(60.3)$ & \\
\hline 41 à 50 ans & $61(15.5)$ & $32(52.5)$ & $29(47.5)$ & \\
\hline 51 à 60 ans & $49(12.4)$ & $27(55.1)$ & $22(44.9)$ & \\
\hline$>60$ ans & $68(17.3)$ & $41(60.3)$ & $27(39.7)$ & \\
\hline Financing of care & & & & 0.655 \\
\hline Enterprise & $257(65.2)$ & $111(43.2)$ & $146(56.8)$ & \\
\hline Private/Personal & $137(34.8)$ & $52(37.9)$ & $85(62)$ & \\
\hline Distance from home & & & & 0.853 \\
\hline$<1$ hour & $354(89.8)$ & $147(41.5)$ & $207(58.5)$ & \\
\hline$>1$ hour & $40(10.2)$ & $16(40)$ & $24(60)$ & \\
\hline Level of education & & & & 0.001 \\
\hline Illiterate & $7(1.8)$ & $5(71.4)$ & $2(28.6)$ & \\
\hline Primary & $27(7)$ & $14(51.9)$ & $13(48.1)$ & \\
\hline Secondary & $66(17.1)$ & $18(27.3)$ & $48(72.7)$ & \\
\hline Superior or university & $287(72.8)$ & $120(41.8)$ & $167(58.2)$ & \\
\hline
\end{tabular}

The data are expressed as a mean \pm standard deviation, absolute frequency $(n)$ and percentage (\%).

\subsection{Indications for Surgery (See Table 2)}

Explorations were the predominant indication (55.1\%) and more concerned men ( $\mathrm{p}<0.001$ ), after which were the following: the OB-GYN indications in $24.1 \%$, ENT in $8.4 \%$, urological in $4.2 \%$, trauma $(4.1 \%)$ and general surgery $2.5 \%$.

\subsection{Operative Procedures (See Table 3)}

Gastroscopy was the most performed exploration (21.6\%) followed by laparoscopy at $12.7 \%$. Endo-uterine aspiration was the most OB-GYN procedure at $14.9 \%$ followed by lumpectomy of the breast at $6.6 \%$. Among ENT cases, adenoidectomy and tonsillectomy were performed in $7.6 \%$ and $0.5 \%$, respectively.

\subsection{Anesthetic Data (See Table 4)}

Almost all of the patients (75.1\%) were classified ASA 1 with significantly higher proportions in women than in men $(65.5 \%$ versus $34.5 \% \mathrm{p}<0.001)$. There were 
no written instructions in $99.7 \%$, or written pain medication prescriptions in 97.9\%. The average procedure duration was one hour and in most cases the procedure lasted about less than an hour and a half, or $98.2 \%$ of cases. Written forrm of PAC were found in $57.8 \%$, those of pre-anesthetic fasting in $96.7 \%$ of patients, with no significant difference between the two groups ( $p>0.05)$. The anesthetic techniques were: propofol narcosis $(80.7 \%)$, general anesthesia with intubation (13.2\%) and spinal anesthesia (4.8\%). The anesthesiologist was senior resident doctor in $65.4 \%$ and the operator was attending doctor in $95.9 \%$.

Table 2. Surgical indications.

\begin{tabular}{|c|c|c|c|c|}
\hline \multirow[b]{2}{*}{ Variables } & \multirow{2}{*}{$\begin{array}{c}\text { All } \\
\mathrm{n}=394\end{array}$} & \multicolumn{2}{|c|}{ Sex } & \multirow[b]{2}{*}{$\mathbf{P}$} \\
\hline & & $\begin{array}{c}\text { Men } \\
\mathrm{n}=163\end{array}$ & $\begin{array}{l}\text { Women } \\
\mathrm{n}=231\end{array}$ & \\
\hline Explorations & $217(55.1)$ & $114(52.5)$ & $103(47.5)$ & \\
\hline OB-GYN pathologies & $95(24.1)$ & & & \\
\hline Pregnancy stopped & $31(7.8)$ & 0 & $31(100)$ & \\
\hline Breast adenofibroma & $26(6.6)$ & 0 & $26(100)$ & \\
\hline Incomplete abortion & $20(5.1)$ & 0 & $20(100)$ & \\
\hline Cervical gaping & $10(2.5)$ & 0 & $10(100)$ & \\
\hline Condylomata & $5(1.3)$ & 0 & $5(100)$ & \\
\hline Placenta retention & $3(0.8)$ & 0 & $3(100)$ & \\
\hline Urological pathologies & $16(4.1)$ & & & \\
\hline Stenosis & $7(1.8)$ & $7(100)$ & 0 & \\
\hline Kidney stones & $5(1.3)$ & $5(100)$ & 0 & \\
\hline Hernia & $3(0.8)$ & $1(33.3)$ & $2(66.7)$ & \\
\hline Vaginal hydrocele & $1(0.3)$ & $1(100)$ & 0 & $<0001$ \\
\hline Orthopaedic pathologies & $16(4.1)$ & & & \\
\hline Fracture & $13(3.3)$ & $11(84.6)$ & $2(15,4)$ & \\
\hline Dislocation & $3(0.8)$ & $1(33.3)$ & $2(66.7)$ & \\
\hline Pathologies ORL & $34(8.6)$ & & & \\
\hline Adenoids & $30(7.6)$ & $11(36.7)$ & $19(63.3)$ & \\
\hline Chronic tonsillitis & $2(0.5)$ & $2(100)$ & 0 & \\
\hline Foreign body ear & $1(0.3)$ & 0 & $1(100)$ & \\
\hline Enchondrome temporal & $1(0.3)$ & 0 & $1(100)$ & \\
\hline General surgery & $10(2.5)$ & & & \\
\hline Abscess & $4(1)$ & 0 & $4(100)$ & \\
\hline Lipome & $2(0.5)$ & $2(100)$ & 0 & \\
\hline Circonsion & $4(1)$ & $4(100)$ & 0 & \\
\hline Other & $6(1.5)$ & $5(83.3)$ & $1(16.7)$ & \\
\hline
\end{tabular}

The data are expressed as a mean \pm standard deviation, absolute frequency (n) and percentage $(\%)$. 
Table 3. Surgical procedures.

\begin{tabular}{|c|c|c|c|c|}
\hline \multirow[b]{2}{*}{ Variables } & \multirow{2}{*}{$\begin{array}{c}\text { All } \\
\mathrm{n}=394\end{array}$} & \multicolumn{2}{|c|}{ Sex } & \multirow[b]{2}{*}{$\mathbf{P}$} \\
\hline & & $\begin{array}{c}\text { Men } \\
\mathrm{n}=163\end{array}$ & $\begin{array}{l}\text { Women } \\
\mathrm{n}=231\end{array}$ & \\
\hline \multicolumn{5}{|l|}{ Explorations } \\
\hline Gastroscopy & $85(21.6)$ & $39(45.9)$ & $46(54.1)$ & \\
\hline Laparoscopy & $50(12.7)$ & 0 & $50(100)$ & \\
\hline Gastro-colonoscopy & $43(10.9)$ & $21(48.8)$ & $22(51.2)$ & \\
\hline Bronchoscopy & $10(2.5)$ & $6(60)$ & $4(40)$ & \\
\hline Cystoscopy & $10(25)$ & $10(100)$ & 0 & \\
\hline MRI and brain ct-scan & $8(2)$ & $7(87.5)$ & $1(12.5)$ & \\
\hline \multicolumn{5}{|l|}{ Gyneco-obstetrics } \\
\hline Uterine aspiration & $59(14.9)$ & 0 & $59(100)$ & \\
\hline Tumorectomy & $26(6.6)$ & 0 & $26(100)$ & \\
\hline Cerclage & $10(2.5)$ & 0 & $10(100)$ & \\
\hline Cauterization & $7(1.7)$ & 0 & $7(100)$ & \\
\hline \multicolumn{5}{|l|}{ Urological } \\
\hline Dilatation & $7(1.7)$ & $7(100)$ & 0 & \\
\hline Double J stent installation & $5(1.2)$ & $5(100)$ & 0 & \\
\hline \multicolumn{5}{|l|}{ Orthopedic } \\
\hline Reduction + restraint & $8(1.5)$ & $3(37.5)$ & $5(62.5)$ & \\
\hline Simple discount & $8(1.5)$ & $4(50)$ & $4(50)$ & \\
\hline Removal of materials & $5(1.2)$ & $3(60)$ & $2(40)$ & \\
\hline \multicolumn{5}{|l|}{ ORL } \\
\hline Adenoidectomy & $30(7.6)$ & $18(60)$ & $12(40)$ & \\
\hline Amygdalectomy & $2(0.5)$ & $1(50)$ & $1(50)$ & \\
\hline \multicolumn{5}{|l|}{ General surgery } \\
\hline Circumcision & $4(1)$ & $4(100)$ & 0 & \\
\hline Lipomectomy & $2(0.5)$ & $2(100)$ & 0 & \\
\hline Other & $15(3.8)$ & $12(80)$ & $3(20)$ & \\
\hline
\end{tabular}

The data are expressed as a mean \pm standard deviation, absolute frequency (n) and percentage (\%).

\subsection{Data on Patient Progress (See Table 5)}

Eleven patients (3.2\%) presented complications (desaturation, hypotension, bradycardia, bradypnea). Prevention of postoperative nausea and vomiting was carried out in $17.5 \%$ of patients, $99.2 \%$ of patients were accompanied, $0.8 \%$ returned to hospital, there was no written record of the score assessment before discharge in $99 \%$ and length of stay was less than 12 hours in $66.4 \%$ and longer in $32.8 \%$. 
Table 4. Anesthetic data from the study population.

\begin{tabular}{|c|c|c|c|c|}
\hline \multirow[b]{2}{*}{ Variables } & \multirow{2}{*}{$\begin{array}{c}\text { All } \\
\mathrm{n}=394\end{array}$} & \multicolumn{2}{|c|}{ Sex } & \multirow[b]{2}{*}{$\mathbf{P}$} \\
\hline & & $\begin{array}{c}\text { Male } \\
n=163\end{array}$ & $\begin{array}{l}\text { Women } \\
\mathrm{n}=231\end{array}$ & \\
\hline ASA Class & & & & $<0.001$ \\
\hline 1 & $296(75.1)$ & $102(34.5)$ & $194(65.5)$ & \\
\hline 2 & $92(23.4)$ & $59(64.1)$ & $33(35.9)$ & \\
\hline 3 & $6(1.5)$ & $2(33.3)$ & $4(66.7)$ & \\
\hline Analgesic prescription/PAC & & & & 0.853 \\
\hline Yes & $8(2.1)$ & $3(37.5)$ & $5(62.5)$ & \\
\hline No & $373(97.9)$ & $152(40.8)$ & $221(59.2)$ & \\
\hline Instructions & & & & 0.399 \\
\hline Yes & $1(0.3)$ & 0 & $1(100)$ & \\
\hline Non & $393(99.7)$ & $163(41.6)$ & $229(58.4)$ & \\
\hline \multicolumn{5}{|l|}{ Procedure duration } \\
\hline $\mathrm{X} \pm \mathrm{ET}$ & $1 \pm 0.1$ & & & 0.692 \\
\hline$<1 \mathrm{~h} 30^{\prime}$ & $387(98.2)$ & $160(41.3)$ & $227(58.7)$ & \\
\hline$>1 \mathrm{~h} 30^{\prime}$ & $7(1.8)$ & $3(42.9)$ & $4(57.1)$ & \\
\hline \multicolumn{5}{|l|}{ Pre-anesthetic fasting } \\
\hline Yes & $381(96.7)$ & $161(42.3)$ & $220(57.7)$ & 0.106 \\
\hline No & $13(3.3)$ & $2(15.4)$ & $11(84.6)$ & \\
\hline \multicolumn{5}{|l|}{ PAC } \\
\hline No & $166(42.2)$ & $74(44.6)$ & $92(55.4)$ & 0.248 \\
\hline Yes & $227(57.8)$ & $88(38.8)$ & $139(61.2)$ & \\
\hline \multicolumn{5}{|l|}{ Anaesthetist qualification } \\
\hline senior & $258(65.5)$ & $107(41.5)$ & $151(58.5)$ & 0.407 \\
\hline Internal & $135(34)$ & $55(40.3)$ & $80(59.7)$ & \\
\hline Anaesthetist Technician & $1(0.3)$ & $1(100)$ & 0 & \\
\hline \multicolumn{5}{|l|}{ Operator Qualification } \\
\hline senior & $374(94.9)$ & $158(42.2)$ & $216(57.8)$ & \\
\hline Internal & $5(1.3)$ & 0 & $5(100)$ & \\
\hline General practitionner & $15(3.8)$ & $5(33.3)$ & $10(66.7)$ & 0.257 \\
\hline \multicolumn{5}{|l|}{ Type of anesthesia } \\
\hline General + Intubation & $52(13.2)$ & $20(38.5)$ & $32(61.5)$ & \\
\hline Spinal Anesthesia & $19(4.8)$ & $13(68.4)$ & $6(31.6)$ & \\
\hline Local anesthesia & $2(0.5)$ & 0 & $2(100)$ & \\
\hline Narcosis (propofol) & $318(80.7)$ & $130(40.9)$ & $188(59.1)$ & 0.105 \\
\hline Block & $2(0.5)$ & 0 & $2(100)$ & \\
\hline Combined & $1(0.3)$ & 0 & $1(100)$ & \\
\hline
\end{tabular}

The data are expressed as a mean \pm standard deviation, absolute frequency (n) and percentage (\%). 
Table 5. Patient evolution data.

\begin{tabular}{|c|c|c|c|c|}
\hline \multirow[b]{2}{*}{ Variables } & \multirow{2}{*}{$\begin{array}{c}\text { All } \\
\mathrm{n}=394\end{array}$} & \multicolumn{2}{|c|}{ Sex } & \multirow[b]{2}{*}{$\mathbf{P}$} \\
\hline & & $\begin{array}{c}\text { Men } \\
\mathrm{n}=163\end{array}$ & $\begin{array}{l}\text { Women } \\
\mathrm{n}=231\end{array}$ & \\
\hline Complications & & & & 0.239 \\
\hline None & $381(96.8)$ & $154(40.4)$ & $227(59.6)$ & \\
\hline Present & $13(3.2)$ & $9(69.3)$ & $4(30.7)$ & \\
\hline Desaturation & $6(1.5)$ & $4(60)$ & $2(40)$ & \\
\hline Hypotension & $3(0.6)$ & $3(100)$ & 0 & \\
\hline Bradycardia & $2(0.5)$ & $2(100)$ & 0 & \\
\hline Bradypnea & $2(0.5)$ & $2(100)$ & 0 & \\
\hline Prevention NVPO & & & & 0.534 \\
\hline Yes & $69(17.5)$ & $29(42)$ & $40(58)$ & \\
\hline Not & $325(85.1)$ & $134(41.2)$ & $191(58.8)$ & \\
\hline Accompanying & & & & 0.777 \\
\hline Present & $391(99.2)$ & $162(41.4)$ & $229(58.6)$ & \\
\hline Absent & $3(0.8)$ & $1(33.3)$ & $2(66.7)$ & \\
\hline Back to hospital & & & & 0.372 \\
\hline Yes & $3(0.8)$ & $2(66.7)$ & $1(33.3)$ & \\
\hline Not & $391(99.2)$ & $161(41.2)$ & $230(58.8)$ & \\
\hline Discharging score & & & & 0.328 \\
\hline CHUNG & $1(0.5)$ & $1(100)$ & 0 & \\
\hline PADSS & $3(0.8)$ & $2(66.7)$ & $1(33.3)$ & \\
\hline No evaluation & $390(99)$ & $160(41)$ & $230(59)$ & \\
\hline Thromboembolic prev. & & & & 0.788 \\
\hline Yes & $2(0.5)$ & $1(50)$ & $1(50)$ & \\
\hline Not & $392(99.5)$ & $167(42.6)$ & $225(57.4)$ & \\
\hline Length of stay & & & & 0.300 \\
\hline $\mathrm{X} \pm \mathrm{ET}$ & $11.9 \pm 6.4$ & $12.4 \pm 6.6$ & $11.7 \pm 6.3$ & \\
\hline$\leq 12$ Hours & $262(66.4)$ & $103(39.3)$ & $159(60.7)$ & \\
\hline$>12$ hours & $132(32.6)$ & $60(45.5)$ & $72(54.5)$ & \\
\hline
\end{tabular}

The data are expressed as a mean \pm standard deviation, absolute frequency $(\mathrm{n})$ and percentage (\%).

\subsection{Main Anesthetic Drugs Used (See Table 6)}

Propofol was the most widely used narcotic (80.2\%) followed by ketamine $6.3 \%$. Halothane was used more than sevoflurane $4.3 \%$ and $1 \%$, respectively (as halogen). Suxamethonium was the most used curare (13.2\%) exceeding vecuronium (3.6\%), rocuronium $(0.8 \%)$ and atracurium $(0.3 \%)$. Fentanyl was the most widely used opioid drug in $14.5 \%$. Bupivacaine was the most used local anesthetic in $10.9 \%$.

\subsection{Determinants of Complications (See Table 7)}

In univariate analysis, the determinants of complications were, age over 37 years, ASA II class and narcosis. In multivariate analysis, the strength of association persisted only for ASA class 2 [ORa: $3.395 \%$ CI $(1.1$ - 9.7) $\mathrm{p}=0.023$ ]. 
Table 6. Main anesthetic drugs used.

\begin{tabular}{|c|c|c|c|c|}
\hline \multirow[b]{2}{*}{ Variables } & \multirow{2}{*}{$\begin{array}{c}\mathrm{N} \\
\mathrm{n}=394\end{array}$} & \multicolumn{2}{|c|}{ Sex } & \multirow[b]{2}{*}{$\mathbf{P}$} \\
\hline & & $\begin{array}{c}\text { Men } \\
n=163\end{array}$ & $\begin{array}{l}\text { Women } \\
\mathrm{n}=231\end{array}$ & \\
\hline \multicolumn{5}{|l|}{ Narcotics } \\
\hline Propofol & $316(80.2)$ & $123(38.9)$ & $193(61.1)$ & \\
\hline Ketamine & $25(6.3)$ & $8(32)$ & $17(68)$ & \\
\hline Midazolam & $36(9.1)$ & $14(38.9)$ & $22(61.1)$ & \\
\hline \multicolumn{5}{|l|}{ Halogenic } \\
\hline Halothane & $17(4.3)$ & $4(23.5)$ & $13(76.5)$ & \\
\hline Sevoflurane & $4(1)$ & $1(25)$ & $3(75)$ & \\
\hline \multicolumn{5}{|l|}{ Curares } \\
\hline Suxamethonium & $52(13.2)$ & $11(21.2)$ & $41(78.8)$ & \\
\hline Vécuronium & $14(3.6)$ & $5(35.7)$ & $9(64.3)$ & 0.034 \\
\hline Atracurium & $1(0.3)$ & 0 & $1(100)$ & \\
\hline Rocuronium & $3(0.8)$ & $1(33.3)$ & $2(66.7)$ & \\
\hline \multicolumn{5}{|l|}{ Analgesics } \\
\hline Fentanyl & $57(14.5)$ & $13(22.8)$ & $44(77.2)$ & \\
\hline Sufentanil & $4(1)$ & $2(50)$ & $2(50)$ & \\
\hline Morphine & $6(1.5)$ & $2(33.3)$ & $4(66.7)$ & \\
\hline \multicolumn{5}{|l|}{ Local anesthestic } \\
\hline Bupivacaine & $43(10.9)$ & $21(48.8)$ & $22(51.2)$ & \\
\hline Xylocaine & $6(1.5)$ & $4(66.7)$ & $2(33.3)$ & \\
\hline
\end{tabular}

Data are expressed as mean \pm standard deviation, absolute frequency $(n)$ and relative frequency (percent).

Table 7. Determinants of complications during outpatient anesthesia.

\begin{tabular}{|c|c|c|c|c|}
\hline \multirow{2}{*}{ Determinants } & \multicolumn{2}{|c|}{ Univariate analysis } & \multicolumn{2}{|c|}{ Multivariate analysis } \\
\hline & $\mathrm{P}$ & OR (IC95\%) & $\mathrm{P}$ & ORa (IC95\%) \\
\hline \multicolumn{5}{|l|}{ Sex } \\
\hline Women & & 1 & & 1 \\
\hline Men & 0.038 & $3.1(0.9-10.2)$ & 0.887 & $1.09(0.3-3.7)$ \\
\hline \multicolumn{5}{|l|}{ Age } \\
\hline$\leq 37 y$ & & 1 & & 1 \\
\hline$>37 y$ & 0.014 & $1.1(1-1.1)$ & 0.301 & $0.3(0.03-2.1)$ \\
\hline \multicolumn{5}{|l|}{ ASA Class } \\
\hline 1 & & 1 & & 1 \\
\hline 2 & 0.004 & $2.1(1.2-3.1)$ & 0.023 & $3.3(1.1-9.7)$ \\
\hline \multicolumn{5}{|c|}{ Type of anesthesia } \\
\hline Others & & 1 & & 1 \\
\hline Narcosis & 0.007 & $3.1(1.1-9.7)$ & 0.146 & $0.9(0.02-2.7)$ \\
\hline
\end{tabular}


Other procedures: lung biopsy, hysteroscopy, lipomectomy, rectoscopy, cystoscopy, double J probe placement, circumcision, herniorraphy, hysteroscopy, foreign body extraction.

\section{Discussion}

Our sample was 394 patients larger than that of Khamouna [7] in Morocco which had 100 patients in a single-center study. The frequency of ambulatory anesthesia in our series is $40.5 \%$, lower than in the last French study that reported a frequency of $55.9 \%$ [6]. Note that our study concerned only a few medical facilities in the city of Kinshasa and the distribution of this practice is disparate.

Ambulatory anesthesia seems to be used much more in young women (58.6\%). Patients under the age of 20 only represented $12.4 \%$, while Khamouna [7] found that $68 \%$ were under 15 years old. The mean age was $39.3 \pm 16.5$ years. The youngest patient was one year old and the oldest was 82 years old, because apart from prematurity there are no age limits for outpatient anesthesia [9].

Graduate instruction level patients were in the majority in 59.2\%, as it takes a certain level of understanding to understand and follow the instructions for this anesthesia. The majority of our patients (89.9\%) took less than an hour to reach medical facilities as per SFAR recommendations [9].

Explorations represented $55.1 \%$ of the indications followed by OB-GYN procedures, unlike Khamouna [7] who noted a predominance of ENT indications in $38 \%$. It seems that, in our community, the teams are still afraid of performing a lot of outpatient surgeries not only because of the level of understanding of the patients, but also of the traffic jams that can delay a fast return of the patient to the hospital in the event of complications.

Our study noted that $75.1 \%$ of the patients were classified ASA I. The ASA II and III patients represented $23.4 \%$ and $1.5 \%$ respectively. These results corroborate the formalized expert recommendations of the 2010 French Society of Resuscitation (SFAR) [9] which establish that ASA I, ASA II and ASA III (stable) patients are eligible for outpatient anesthetic treatment. Khamouna's study [7] did not register ASA III patients because they were not included.

Written recommendations were given to only one patient out of the 394 (i.e. $0.3 \%$ ), this is explained by the fact of our oral tradition probably, the operators in this modality of care were limited to verbal instructions while the 2010 formalized recommendations from the experts of the French Society and Resuscitation (SFAR) [9] of require the mandatory submission of an information document (instructions) after oral information. However, there is no such legislation in the Democratic Republic of the Congo.

In this study, the proportion of patients who benefited from the pre-anesthetic Consultation (PAC) was 57.8\%, the patients who were not consulted by an anesthesiologist prior to the procedure were those who were assessed on the day of the procedure. This reality deviates from the 2010 formalized recommenda- 
tions of the French Society of Resuscitation (SFAR) experts [9], which require patients to be consulted by an anesthesiologist at least 48 hours earlier to allow them to make necessary arrangements (on pre-operative fasting, on habits, explanations on the different anesthetic protocols...).

Pre-anesthetic fasting was effective in $96.7 \%$ of patients. Other authors such as Warner MA in 1999 [10] and Pandit SK in 2000 [11] as well as the recommendations of the ASA [10] [11] insist on this preoperative fast to avoid both inhalations and the disadvantages of prolonged fasting. The average duration of intervention was one hour and in most cases, the intervention lasted about one hour and thirty minutes, i.e. $98.2 \%$ of cases according to the 2010 formalized recommendations of SFAR experts [9].

Narcosis was the most widely used type of anesthesia (82.4\%) because it is best suited to short lasting procedures. Propofol has been the most widely used narcotic because of its good kinetics as other authors had suggested [12] [13]. Suxamethonium was the most used curare in our study (13.2\%). It is used to facilitate tracheal intubation but exposes the patient to postoperative myalgia related to fasciculation (in $5 \%$ to $10 \%$ of cases especially if the rise and ambulation are early, which is the rule in outpatient settings). In our study, it was used without this adverse effect. Although Lemmens [14] has established since 1998, that the morphinics to be preferred on an outpatient basis are remifentanil, alfentanil and sufentanil because of their rapid elimination, fentanyl was used in $14.5 \%$ in our series because of its availability on the market so morphinics less prone to residual effects are rare on the local market.

In this study, eleven patients had complications (3.2\%): desaturation, hypotension, bradycardia and bradypnea. In a Matthew meta-analysis [12], the mean rates of airwayevents (partial or complete obstruction, apnea and hypoxia) and haemodynamic events (low blood pressure, arrhythmia, tachycardia, bradycardia) were $1.44 \%$. Our complication rate exceeds Matthew's because he had only worked on sedations.

Almost all patients were accompanied as recommended [9]. The majority of patients were almost not assessed before being discharged, only 3 patients out of the 394 i.e. $0.8 \%$ were assessed by the Chung score. An attitude that deviates from the principles of outpatient anesthetic care. As a matter of fact, it is the lack of a document proving this evaluation that is missing and not the consultation itself. The proportion of patients who benefited from thromboembolic prevention was $0.5 \%$. Here we must qualify the fact that our series had no major interventions. But this is one of the advantages offered by this mode of care [15]. The average length of stay was $11.9 \pm 6.4$ hours and most patients had stayed more than 12 hours (67.3\%), this result corroborates the conception of Anglo-Saxon countries on outpatient anesthetic care ( $<24$ hours) [4].

In this study, only ASA II class [ORa: 3.3\% CI 1.1 - 9.7) $\mathrm{p}=0.023$ ] appeared to be the determinant of complications. This result is different from Ansell's observation in 1998 [16] who retrospectively assessed the outcome of patients fol- 
lowing outpatient surgery. Among the 30,000 outpatients managed on an outpatient basis between 1998 and 2002, 3.3\% were classified as ASA III. Compared with an ASA I or II control group, matched in age, sex, type and year of intervention, the incidence of postoperative complications was similar in both groups. Similarly, the percentage of unplanned hospitalization was comparable $(2.9 \%$ and $1.9 \%$ for ASA III and ASA I or II patients respectively) [16]. However, the under-representation of ASA III patients in our study should be noted.

Limitations of the study:

- This study does not allow a direct comparison of the advantages (benefits) of ambulatory anesthesia to conventional hospitalization.

- The non-follow-up of patients who have benefited from ambulatory anesthesia after their discharge from hospital.

\section{Conclusions}

Ambulatory anesthesia is a reality in the city of Kinshasa; however, it is still underdeveloped with different frequencies depending on the hospital.

Half of outpatient anesthesia is indicated for explorations (gastroscopy, colonoscopy, laparoscopy, etc.). But it is also worth noting some essentially minor interventions. Almost all patients are classified as ASA I and these procedures are most often performed by senior doctors. Propofol is the most widely used narcotic. Complications, although rare, are related to class ASA II.

There is clearly interest in broadening the indications to make it a priority axis for the development of surgery, anesthesia and a source of health savings, as in Western countries. An effort should also be made to comply with the recommendations of learned societies.

\section{Authors' Contribution}

- Tsangu Joseph designed, collected, interpreted, wrote the manuscript;

- Longo-Mbenza Benjamain coordinated the writing of the article;

- Mfulani Gibency carried out the statistical analyses;

- Mbombo Wilfrid and the others corrected the manuscript.

\section{Conflicts of Interest}

The authors declare no conflicts of interest regarding the publication of this paper.

\section{References}

[1] International Association for Ambulatory Surgery (2007) Policy Brief "Day Surgery: Making It Happen".

[2] Zetlaoui, P.J. (2015) Anesthésie ambulatoire. EM Consulte.

[3] Massa, H., Hubert, S., Carles, M. and Raucoules-Aimé, M. (2010) Anesthésie du patient ambulatoire. Anesthésie \& Réanimation, 36, 635-636.

[4] Kraft, K., Mariette, C., Sauvanet, A., et al. (2011) Indications for Ambulatory Ga- 
strointestinal and Endocrine Surgery in Adults. Journal of Visceral Surgery, 148, 69-74.

[5] International Association for Ambulatory Surgery (2009) Enquête sur le taux de la chirurgie ambulatoire.

[6] Association Française de Chirurgie Ambulatoire (2018) Taux de chirurgie ambulatoire de 2017: Un ralentissement de sa croissance qui interroge sur l'objectif de $70 \%$ en 2022. https://www.chirurgie-ambulatoire.org

[7] Younès, K. (2010) L'anesthésie pour chirurgie ambulatoire: Réalités et perspectives. A propos de 100 cas. Thèse de l'Université de Cadi Ayyad, Faculté de Medecine et de Pharmacie Marrakech, Marrakech, $101 \mathrm{p}$.

[8] Luty, A.N., Tshipukane, D.N., Sokolo, J., Kalombo, T. and Matanda, R. (2016) Indications d'amygdalectomie à Lubumbashi: Profil clinique. Médecine d Afrique Noire, 63, 525-532.

[9] Socièté Française d'Anesthésie et Réanimation (2010) Prise en charge anesthésique des patients en hospitalisation ambulatoire. Recommandations d'experts. Annales Françaises d Anesthésie et de Réanimation, 29, 67-92.

[10] Warner, M.A., Kaplan, R.A., Epstein, B.S., Gibbs, C.P., Keller, C.E., Leak, J.A., et al. (1999) Practice Guidelines for Preoperative Fasting and the Use of Pharmacologic Agents to Reduce the Risk of Pulmonary Aspiration: Application to Healthy Patients Undergoing Elective Procedures. A Report by the American Society of Anesthesiologists Task Force on Preoperative Fasting. Anesthesiology, 90, 896-905. https://doi.org/10.1097/00000542-199903000-00034

[11] Pandit, S.K., Loberg, K.W. and Pandit, U.A. (2000) Toast and Tea before Elective Surgery? A National Survey on Current Practice. Anesthesia \& Analgesia, 90, 13481351. https://doi.org/10.1097/00000539-200006000-00016

[12] Chan, M.T.V., Wu, W.K.K. and Tang, R.S.Y. (2015) Optimizing Depth of Sedation for Colonoscopy. Canadian Journal of Anesthesial Journal Canadien d Anesthésie, 62, 1143-1148. https://doi.org/10.1007/s12630-015-0462-4

[13] Mark, P.E. (2004) Propofol: Therapeutic Indications and Side-Effects. Current Pharmaceutical Design, 10, 3639-3649. https://doi.org/10.2174/1381612043382846

[14] Lemmens, H.J., Bovill, J.G., Burn, A.G. and Hennis, P.J. (1998) Alfentanil Infusion in the Elderly: Prolonged Computer-Assisted Infusion of Alfentanil in the Elderly Surgical Patient. Anaesthesia, 43, 850-856. https://doi.org/10.1111/j.1365-2044.1988.tb05598.x

[15] Leleu, E. and Kraft, K. (2015) Retours d'expérience en chirurgie ambulatoire. Evolutions des pratiques d'anesthésie et de chirurgie sur l'utilisation des produits de

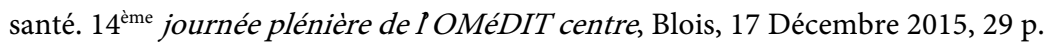

[16] Ansell, G.L. and Montgomry, J.E. (1998) Outcome of ASA III Patients Undergoing Day Case Surgery. British Journal of Anaesthesia, 92, 71-74. 